\title{
Reduced Haematological Indices in Auto-Mechanics and Fuel Attendants in Elele Nigeria
}

\author{
Anslem O. Ajugwo 1,*, Teddy C. Adias ${ }^{2}$, Kevin Aghatise ${ }^{3}$, Johnson K. Fadairo ${ }^{3}$, Clement U. Nyenke ${ }^{4}$ \\ ${ }^{1}$ Department of Haematology and Blood Transfusion, Madonna University Elele, Nigeria \\ ${ }^{2}$ Bayelsa State College of Health Technology Ogbia, Nigeria \\ ${ }^{3}$ Department of Medical Laboratory Science, Achievers University Owo, Nigeria \\ ${ }^{4}$ Department of Medical Laboratory Science, Rivers State University of Science and Technology, Rivers State \\ *Corresponding author: slemjugwo@yahoo.com
}

Received December 24, 2013; Revised January 07, 2014; Accepted February 06, 2014

\begin{abstract}
Gasoline is largely a mixture of hydrocarbon and hydrocarbon consists of mixture of n-paraffins, naphthalene, olefins and aromatics. Aromatics is mostly a mixture of benzene, toluene and xylene. Fuel attendants and auto mechanics are exposed to gasoline either by direct contact or inhalation. The effect of this exposure in fuel attendants and auto mechanics is determined using haematological parameters. 35 fuel attendants and 35 auto mechanics were used as test group and compared with 30 apparently healthy individuals of same age range. Some haematological parameters were determined using standard manual methods. RBC, $\mathrm{Hb}, \mathrm{MCH}$ and MCHC were reduced $(\mathrm{p}<0.05)$ in fuel attendants and auto mechanics when compared with control. Fuel attendants exposed to gasoline fumes beyond 2 years have lower $(\mathrm{p}<0.05) \mathrm{PCV}, \mathrm{Hb}, \mathrm{MCH}$ and MCHC than those exposed for 2 years or less while auto mechanics of over two years had their RBC, Hb, MCH and MCHC significantly lower ( $<0.05)$ than auto mechanics of two years and below. Auto mechanics and fuel attendants are exposed to gasoline vapour leading to decreased haematological indices. Fuel attendants are more at risk than auto mechanics and could be at risk of developing anaemia over time.
\end{abstract}

Keywords: gasoline, fuel attendants, auto mechanics, haematological parameters, anaemia

Cite This Article: Anslem O. Ajugwo, Teddy C. Adias, Kevin Aghatise, Johnson K. Fadairo, and Clement U. Nyenke, "Reduced Haematological Indices in Auto-Mechanics and Fuel Attendants in Elele Nigeria." American Journal of Medical and Biological Research, vol. 2, no. 1 (2014): 1-4. doi: 10.12691/ajmbr-2-1-1.

\section{Introduction}

Gasoline is a complex manufactured mixture that does not exist naturally in the environment. Chemicals that are in gasoline are generally present in several physical states (gaseous, liquid or others) in human settlements [1]. Gasoline is produced from petroleum in the refining process. Exposure to automotive gasoline most likely occur from breathing in its vapour at a service station while filling a car's fuel tank, sniffing by activities of mechanics, while refuelling generators at home, by activities of black market gasoline dealers, workers involved in the clean up and maintenance of underground storage tanks, using equipment that runs on gasoline e.g. lawn mower and drinking gasoline contaminated water [2]. Occupational exposure to petroleum fumes have been reported to have toxic effects on various organs and systems and these include respiratory, immune and nervous system. Organs such as the heart, lungs, skin and kidneys are affected by these toxic effects resulting in various diseases [3].

The haematotoxic effect of benzene have been reported to involve both bone marrow depression and leukaemogenesis caused by damage to multiple classes of haematopoietic cells with a variety of functions [4]. Inhalation exposure of rats to gasoline are irritating to the lungs when breathed in and irritating to the lining of the stomach when swallowed [5].

Breathing in high levels of gasoline for short period of time or swallowing large amounts of gasoline may also cause harmful effects on the nervous system [6]. These effects become more serious as the amount of gasoline breathed in or swallowed increases.

Fuel attendants also called filling station attendants, gas station attendant, gas tender [7], perform duties at automobile service stations as requested by customers; they fill fuel tank vehicles with gasoline or diesel fuel to level specified by customers; observes level of oil in crankcase and amount of water in radiator and adds required amount of oil and water; adds necessary amount of water to battery and washes windshield of vehicle. Checks tires for correct air pressure and handling cash payments or preparing charge slips for credit card customers [7].

An auto mechanic is a mechanic with a variety of car makes or in a specific make of car. In repairing cars, their main role is to diagnose the problem accurately and quickly; they often have to quote price for their customers before commencing work or after partial disassembly for inspection. The mechanic uses both electronic means of 
gathering data as well as their senses. Their job may involve the repair of a specific part or the replacement of one or more parts as assembly [8]. The auto mechanics are commonly exposed to gasoline by sucking with their mouth through a tube in an attempt to siphon gasoline from the vehicle tank. They also wash vehicle parts with gasoline without any gloves. Fuel attendants are exposed by dispensing the fuel into vehicles without any protective device to minimize their exposure. In the process auto mechanics and fuel attendants inhale and have skin/eye contact with gasoline and auto mechanics are also at risk of ingesting the gasoline [9].

Human exposure to gasoline usually present with adverse effects on health depending on the route of exposure and quantity of gasoline involved. Various degrees of toxicities are also associated with gasoline inhalation and sometimes anaemia and other disease condition may result. We therefore set out to determine these effects in our immediate environment.

\section{Materials and Methods}

\subsection{Study Area}

The study was carried out in Elele, Rivers State, SouthSouth of Nigeria.

\subsection{Research Population}

This study was carried out on adult volunteers aged between 18-30 years, who gave informed consent to the study. The test subjects were randomly selected from several fuel stations and mechanic workshops in Elele, Rivers State, while the control group is made up of students within the same age bracket.

Questionnaires were distributed and accurately filled. A total of One hundred subjects participated in this study. Of the seventy test group, thirty five were fuel attendants while the remaining thirty five consists of auto mechanics. The control group consists of thirty subjects. Both males and females were used in this study.

Each test group was further divided into: years or less)

Test $2\left(\mathrm{~T}_{2}\right)$ (fuel attendants that have worked for more than two years)

Test $A\left(T_{A}\right)$ (auto mechanics that have worked for two years or less)
Test $1\left(\mathrm{~T}_{1}\right)$ (fuel attendants that have worked for two

Test $\mathrm{B}\left(\mathrm{T}_{\mathrm{B}}\right)$ (auto mechanics that have worked for more than two years).

\subsection{Inclusion / Exclusion Criteria}

The study was limited to fuel attendants who were exposed to gasoline and/or inhaled gasoline when dispensing to automobiles and auto mechanics that use gasoline to wash engine parts, siphon gasoline from fuel tank and in the process inhale gasoline and are willing to participate. Those fuel station attendants and other groups that form part of the mechanic workshop who are not exposed to gasoline were excluded from the study.

\subsection{Sample Collection}

Five millilitres ( $5 \mathrm{mls}$ ) of venous blood was taken from a peripheral vein on the arm of each subject and immediately transferred into sterile Potassium EDTA anticoagulant bottles.

\subsubsection{Ethical Clearance}

This research was approved by the ethical committee of the institution and was monitored during the duration of the research. Rules and guidelines governing sample collection from humans and processing for research purposes were strictly adhered to.

\subsubsection{Sample Analysis}

The blood samples were analysed within 4 hours of collection. Packed Cell Volume (PCV) and haemoglobin concentration $(\mathrm{Hb})$ were analysed using microhaematocrit and cyanmethaemoglobin methods respectively. While Red Blood Cell count (RBC) and White Blood Cell count (WBC) were analysed by diluting with formol-citrate and Turks fluid respectively using standard manual methods [10]. Mean Cell Volume (MCV), Mean Cell Haemoglobin $(\mathrm{MCH})$ and Mean Cell Haemoglobin Concentration (MCHC) were calculated by substituting the values of $\mathrm{PCV}, \mathrm{Hb}$ and RBC appropriately.

\subsubsection{Data Analysis}

The results gotten were analysed using Statistical Package for Social Science (SPSS) version 14. P values < 0.05 were considered significant while $\mathrm{p}$ values $>0.05$ were considered as not significant.

\section{Result}

Table 1. Age and sex distribution of study subjects

\begin{tabular}{llllllc}
\hline \multirow{2}{*}{ Age range(Years) } & \multicolumn{3}{c}{$\begin{array}{c}\text { Fuel attendants } \\
\text { N (\%) }\end{array}$} & \multicolumn{2}{c}{$\begin{array}{c}\text { Auto mechanics } \\
\text { N (\%) }\end{array}$} & \multicolumn{2}{c}{$\begin{array}{c}\text { Control } \\
\text { N (\%) }\end{array}$} \\
\cline { 2 - 7 } & Male & Female & Male & Female & Male & Female \\
\hline $15-20$ & $7(20)$ & $4(11)$ & $15(43)$ & $0(0)$ & $9(17)$ & $7(23)$ \\
$21-25$ & $5(14)$ & $8(23)$ & $10(29)$ & $0(0)$ & $6(20)$ & $4(13)$ \\
$26-30$ & $5(14)$ & $6(17)$ & $10(29)$ & $0(0)$ & $4(13)$ & $4(13)$ \\
Total & $17(49)$ & $18(51)$ & $35(100)$ & $0(0)$ & $15(50)$ & $15(50)$ \\
Grand total & $35(100)$ & & $35(100)$ & & $30(100)$ & \\
\hline
\end{tabular}

Table 2. Haematological indices of auto mechanics, fuel attendants and control

\begin{tabular}{cccc}
\multicolumn{2}{c}{ Table 2. Haematological indices of auto mechanics, fuel attendants and control } \\
\hline Haematological indices & Control & Auto mechanic & Fuel attendants \\
\hline RBC $\left(\times 10^{12} / \mathrm{l}\right)$ & $5.42 \pm 0.71$ & $5.28 \pm 0.60$ & $4.88 \pm 0.67$ \\
WBC $\left(\times 10^{9} / \mathrm{l}\right)$ & $5.65 \pm 1.34$ & $5.04 \pm 1.13$ & $5.50 \pm 1.37$ \\
PCV (\%) & $43.09 \pm 4.93$ & $43.34 \pm 3.60$ & $39.29 \pm 3.98$ \\
Hb (g/dl) & $13.55 \pm 1.49$ & $13.68 \pm 1.14$ & $\mathrm{P}>0.05$ \\
MCV (fl) & $79.63 \pm 6.12$ & $79.10 \pm 6.79$ & $12.50 \pm 1.33$ \\
MCH (pg) & $25.99 \pm 2.24$ & $24.37 \pm 2.82$ & $77.91 \pm 5.78$ \\
MCHC (g/dl) & $31.74 \pm 0.98$ & $30.89 \pm 1.21$ & $24.67 \pm 2.64$ \\
$\mathrm{P}<0.05$ & $\mathrm{P}>0.05$ \\
$\mathrm{P}<0.05$ & $\mathrm{P}<0.05 \pm 1.96$ \\
\hline
\end{tabular}

Results are presented as Mean \pm S.D. P value is significant at $\mathrm{p}<0.05$ 
Table 3. Haematological indices in fuel attendants exposed through inhalation to gasoline fumes

\begin{tabular}{cccccc}
\hline $\begin{array}{c}\text { Haematological } \\
\text { indices }\end{array}$ & $\begin{array}{c}\text { Non-fuel attendants } \\
\text { (control) }\end{array}$ & $\begin{array}{c}\text { Fuel attendants exposed to fume } \leq \\
\text { 2years }\left(\mathrm{T}_{1}\right)\end{array}$ & (p Value) & $\begin{array}{c}\text { Fuel attendants exposed to } \\
\text { fume }>2 \text { years }\left(\mathrm{T}_{2}\right)\end{array}$ & (p Value) \\
\hline RBC $\left(\times 10^{12} / \mathrm{l}\right)$ & $5.42 \pm 0.71$ & $5.00 \pm 0.78$ & $\mathrm{P}>0.05$ & $4.76 \pm 0.52$ & $\mathrm{P}<0.05$ \\
WBC $\left(\times 10^{9} / \mathrm{l}\right)$ & $5.65 \pm 1.34$ & $5.55 \pm 1.23$ & $\mathrm{P}>0.05$ & $5.45 \pm 1.53$ & $\mathrm{P}>0.05$ \\
$\mathrm{PCV}(\%)$ & $43.09 \pm 4.93$ & $39.38 \pm 4.29$ & $\mathrm{P}<0.05$ & $39.20 \pm 3.69$ & $\mathrm{P}<0.05$ \\
Hb (g/dl) & $13.55 \pm 1.49$ & $12.69 \pm 1.44$ & $\mathrm{P}<0.05$ & $12.31 \pm 1.20$ & $\mathrm{P}<0.05$ \\
MCV (fl) & $79.63 \pm 6.12$ & $78.01 \pm 5.72$ & $\mathrm{P}>0.05$ & $77.81 \pm 5.91$ & $\mathrm{P}>0.05$ \\
MCH (pg) & $25.99 \pm 2.24$ & $24.86 \pm 2.72$ & $\mathrm{P}>05$ & $\mathrm{P}<0.05$ \\
MCHC (g/dl) & $31.74 \pm 0.98$ & $31.52 \pm 1.83$ & $\mathrm{P}>0.05$ & & \\
\hline
\end{tabular}

Results are presented as Mean \pm SD. $p$ value is significant at $\mathrm{p}<0.05$

Table 4. Haematological indices in Auto mechanics exposed through inhalation to gasoline fumes

\begin{tabular}{ccccc}
\hline $\begin{array}{c}\text { Haematological } \\
\text { indices }\end{array}$ & $\begin{array}{c}\text { Non-Auto mechanic } \\
\text { (control) }\end{array}$ & $\begin{array}{c}\text { Auto mechanic exposed to fume } \leq \\
\text { 2years }\end{array}$ & (p Value) & $\begin{array}{c}\text { Auto mechanic exposed to } \\
\text { fume }>2 \text { years }\end{array}$ \\
\hline RBC $\left(\times 10^{12} / \mathrm{l}\right)$ & $5.42 \pm 0.71$ & $5.38 \pm 0.64$ & $\mathrm{P}<0.05$ & $5.18 \pm 0.55$ \\
WBC $\left(\times 10^{9} / \mathrm{l}\right)$ & $5.65 \pm 1.34$ & $4.87 \pm 1.01$ & $\mathrm{P}<0.05$ & $5.22 \pm 1.34$ \\
PCV $(\%)$ & $43.09 \pm 4.93$ & $43.78 \pm 4.23$ & $\mathrm{P}>0.05$ & $42.88 \pm 2.77$ \\
Hb (g/dl) & $13.55 \pm 1.49$ & $13.79 \pm 1.32$ & $\mathrm{P}<0.05$ & $13.57 \pm 0.92$ \\
MCV (fl) & $79.63 \pm 6.12$ & $79.31 \pm 7.72$ & $\mathrm{P}>0.05$ & $78.88 \pm 5.77$ \\
MCH (pg) & $25.99 \pm 2.24$ & $24.41 \pm 2.87$ & $\mathrm{P}<0.05$ & $24.33 \pm 2.80$ \\
MCHC (g/dl) & $31.74 \pm 0.98$ & $30.94 \pm 1.06$ & $\mathrm{P}>0.05$ & $\mathrm{P}<0.05$ \\
$\mathrm{P}>0.05$ & $\mathrm{P}<0.05$ \\
\hline
\end{tabular}

Results are presented as Mean \pm S.D. $p$ value is significant at $\mathrm{p}<0.05$

\section{Discussion}

As expected, the number of females involved in automechanic in nil compared to the male counterparts in our study area (Table 1). This demonstrates that automechanic is still regarded as male profession though there are still very few females venturing into the profession. This is in agreement with societal norms that pre dispose the male folk to more difficult tasks than females. From Table 2, RBC, Hb, MCH and MCHC are more reduced in fuel attendants than auto mechanics when compared with the control $(p<0.05)$. These could be due to the effects of benzene and xylene, as reported by [11], benzene causes pancytopenia and could lead to bone marrow aplasia, while xylene has been found to cause leucopenia. These changes could lead to impaired migration of phagocytic cells, lower resistance to viruses, bacteria and foreign bodies [12]. Gasoline is largely a mixture of hydrocarbon and hydrocarbon consists of mixture of n-paraffins, naphthalene, olefins and aromatics. Aromatics is mostly a mixture of benzene, toluene and xylene [13].

Previous studies have also documented significant changes in RBC, Hb, MCH and MCHC in subjects who are exposed to gasoline [14,15]. The toxic components especially those in petroleum fumes, have been reported to change blood chemistry and induce anaemia by causing bone marrow hypoplasia in experimental animals [12]. This study suggests a similar effect on humans. Benzene and lead are toxic constituents of gasoline. They become activated in the bone marrow and the cytotoxic effects observed are mediated through disturbance in DNA function. The resultant bone marrow depression is characterized by inadequate production of red cell and other formed elements [16]. This correlates with the findings in this study.

Fuel attendants exposed to gasoline fumes beyond 2 years have lower ( $\mathrm{p}<0.05) \mathrm{PCV}, \mathrm{Hb}, \mathrm{MCH}$ and $\mathrm{MCHC}$ than those exposed for 2 years or less (Table 3). Length/duration of exposure plays a role in affecting haematological indices. This conforms to previous works of $[3,9]$. This is due to bone marrow depression which is characterized by inadequate production of red cell and other formed elements as reported by [16]. A similar scenario was also observed in the auto mechanics group as shown in Table 4. Auto mechanics of over two years had their RBC, Hb, MCH and MCHC significantly lower ( $\mathrm{p}<$ 0.05 ) than auto mechanics of two years and below. This shows an association between length of exposure and effect on haematological indices.

The fuel attendants had slightly lower $(\mathrm{p}<0.05)$ mean values for some haematological indices than auto mechanics. Some of them admitted going into the underground storage to measure the volume of gasoline, a very dangerous practice. Equally, some of them are involved in offloading gasoline supplies from the supply truck to the underground storage which also predisposes to heavy exposures. The heat generated in the underground facility produces more gasoline fumes which have little escape route. It is therefore hazardous to enter into such enclosure.

\subsection{Conclusion}

This study has shown that auto mechanics and fuel attendants are exposed to gasoline vapour leading to decreased haematological indices. Fuel attendants are more at risk than auto mechanics and could be at risk of developing anaemia.

\section{List of Abbreviations}

\author{
Pg - picogram \\ Fl - femtolitre \\ RBC - Red blood cell count \\ WBC - White blood cell count \\ PCV - Packed cell volume \\ HB - Haemoglobin concentration \\ MCV - Mean cell volume \\ $\mathrm{MCH}$ - Mean cell haemoglobin \\ MCHC - Mean cell haemoglobin concentration
}

\section{References}

[1] Ainsworth, R. W. "Petrol Vapour Poisoning”. British Medical Journal. 1. 1547-1548. 1960.

[2] Smith, J. H., Mallet, A. K. and Brantom, P. G. "Ninety days of Feeding Study in Fisher-344 Rats of Highly refined Petroleum 
Derived Food Grade White Oils and Waves”. Toxicolpathology. 24. 214-230. 1996.

[3] Okoro, A. M., Ani, E. J., Ibu, O. J., Akpogomeh, B. A. "Effect of Petroleum Products Inhalation on some Haematological Indices of Fuel attendants in Calabar Metropolis, Nigeria”. Nigeria Journal of Physiological Science. 21 (2). 71-75. 2006.

[4] Ueng, T. H., Hwang, W. P., Chom, R. M., Wang, H. W., Kuo, M. L., Park, S. S. and Guengerich F.P. "Effects of Motorcycle Exhaust Fume on Cyt P450 Dependent Monooxygenases and GSH-S-Transferase in Red Tissues". Journal Toxicology Environmental Health. 54 (7). 509-527. 1998.

[5] Wixtron, R. N. and Brown, S. L. "Individual and Population Exposure to Gasoline". Journal Exposure Analogue Environmental Epidemiology. 2. 23-28. 1992.

[6] Banner, W. and Walson, P. D. "Systemic Toxicity following Gasoline aspiration”. America Journal Emergency Medicine. 1. 292-294. 1983

[7] Wright, T. “Automobile Service Station Attendants”. California Occupational Guide. 916 (30). 2160-2162.1998.

[8] Barowski, B. Auto mechanic and Action. June 2011. [online]. Available: http:/en.wikipedia.org/w/index.php.[Accessed July 11 2011].

[9] Udonwa, N. E., Uko, E. K., Ikpeme, B.M., Ibanga, I. A. and Okon, B. O. "Exposure of petrol station Attendants and Auto Mechanics to Premium Motor Spirit Fumes in Calabar, Nigeria”. Journal of Environmental Public Health. 10. 1155-1161. 2009.

[10] Cheesbrough, M. Haematological tests. In District laboratory practice in tropical countries. Part 2 Cambridge University Press, London. 2000. 297-305.

[11] D’Azevedo, P. A., Tannhauser, A. L. and Tannhauser, S. L. "Haematological Alternations in Rats from Xylene and Benzene". Vetinary Human Toxicology. 38 (5). 340-344. 1996.

[12] Marieb, E. N. Human Anatomy and Physiology. $3^{\text {rd }}$ ed. Benjamin and Cummings Pub. Co, California. 1995. 585-611.

[13] 40 CFR 141:61. Maximum contaminant levels for organic contaminants.

[14] Dede, E. B. and Kagbo, H. D. “A Study on the acute toxicological effects of commercial diesel fuel in Nigeria in rats ( Ratus ratus) using haematological parameters". Journal of Applied Sciences and Environmental Management. 6 (1). 84-86. 2002.

[15] Ovuru, S. S. and Ekweozor, I. K. E. "Haematological Changes Association with Crude Oil Ingestion in Experimental Rabbits". African Journal of Biotechnology. 3 (6). 346-348. 2004.

[16] Rabble, G. K., and Wong, O. "Leukaemia Mortality by Cell Type in Petroleum Workers with Potential Exposure to Benzene". Environmental Health Perspective. 104. 1381-1392. 1996. 